\title{
The research on the immuno-modulatory defect of Mesenchymal Stem Cell from Chronic Myeloid Leukemia patients
}

\author{
Zhu Xishan*, An Guangyu, Song Yuguang and Zhang Hongmei
}

\begin{abstract}
Overwhelming evidence from leukemia research has shown that the clonal population of neoplastic cells exhibits marked heterogeneity with respect to proliferation and differentiation. There are rare stem cells within the leukemic population that possess extensive proliferation and self-renewal capacity not found in the majority of the leukemic cells. These leukemic stem cells are necessary and sufficient to maintain the leukemia. While the hematopoietic stem cell (HSC) origin of CML was first suggested over 30 years ago, recently CML-initiating cells beyond HSCs are also being investigated. We have previously isolated fetal liver kinase-1-positive $\left(\mathrm{Flk} 1^{+}\right)$cells carrying the BCR/ABL fusion gene from the bone marrow of Philadelphia chromosome-positive $\left(\mathrm{Ph}^{+}\right)$patients with hemangioblast property. Here, we showed that CML patient-derived Flk1 ${ }^{+} \mathrm{CD} 31^{-} \mathrm{CD} 34^{-} \mathrm{MSC}$ had normal morphology, phenotype and karyotype but appeared impaired in immuno-modulatory function. The capacity of patient Flk $1^{+} \mathrm{CD} 31^{-} \mathrm{CD} 34^{-} \mathrm{MSCS}$ to inhibit T lymphocyte activation and proliferation was impaired in vitro. CML patient-derived MSCs have impaired immuno-modulatory functions, suggesting that the dysregulation of hematopoiesis and immune response may originate from MSCs rather than HSCs. MSCs might be a potential target for developing efficacious cures for CML.
\end{abstract}

\section{Introduction}

Chronic Myeloid Leukemia(CML) is a malignant myeloproliferative disorder originating from a pluripotent stem cell that expresses the BCR/ABL oncogene and is characterized by abnormal release of the expanded, malignant stem cell clone from the bone marrow into the circulation $[1,2]$. The discovery of the Philadelphia chromosome followed by identification of its BCR/ABL fusion gene product and the resultant constitutively active $\mathrm{P} 210 \mathrm{BCR} / \mathrm{ABL}$ tyrosine kinase prompted the unravelling of the molecular pathogenesis of CML. However, regardless of greatly reduced mortality rates with BCR/ABL targeted therapy, most patients harbor quiescent CML stem cells that may be a reservoir for disease progression to blast crisis. Under steady-state conditions, these cancer stem cells are localized in a microenvironment known as the stem cell "niche", where they are maintained in an undifferentiated and

\footnotetext{
*Correspondence: mountain.red@163.com

Institute of Medical Oncology, Beijing Shijitan Hospital, Capital Medical University, Beijing, 100038, P.R. China
}

(c) 2011 Xishan et al; licensee BioMed Central Ltd. This is an Open Access article distributed under the terms of the Creative Commons Attribution License (http://creativecommons.org/licenses/by/2.0), which permits unrestricted use, distribution, and reproduction in any medium, provided the original work is properly cited. quiescent state. These niches are critical for regulating the self-renewal and cell fate decisions, yet why and how these cells are recruited to affect leukemia progression are not well known.

Local secretion of proteases has been implicated in this tumor-stroma crosstalk. Matrix metalloproteinase-9 (MMP-9) is one of the proteases that has the preferential ability to degrade denatured collagens (gelatin) and collagen type IV, the 2 main components of basement membranes and therefore plays a critical role in tumor progression and metastasis[3,4]. Previous studies have demonstrated localization of MMP-9 on the plasma membrane of various tumor cells[5-7] and recently, the role of MMP-9 in CML pathogenesis has became a focus of attention[8-11]. But the research is mainly focusing on the MMP-9 inducing molecules[12-14] or the effect of MMP-9 inhibitors[15]. However, it has become clear that the role of MMP-9 in CML is not limited to simple extracellular matrix (ECM) degradation[16]. The regulation of MMP-9 is found to be involved in multiple pathways induced by different kinds of cytokines in different cell types and illness[17,18]. 
Therefore, it is necessary to verify a specific MMP-9 induced pathway in a given cell type.

Recent research $[6,10,4]$ showed that $\mathrm{T}$ lymphocytes isolated from CML patients suppressed the forming of CFU-GM (colony forming unit-granulocyte and macrophage) and CFU-E (colony forming unit-erythroid) and furthermore this kind of inhibition could be blocked by CsA(cyclosporine A) $[19,20]$; besides, the rate of the forming of the HSCs (hematopoietic stem cells) increased with the removal of $\mathrm{T}$ lymphocytes. Therefore, immunological inhibitors like CsA. and ATG (antihuman thymocyte globulin) was helpful for CML patients and was widely used in clinic therapy[21-23]. All these evidence indicated there might existed immunological abnormalities, that is, the $\mathrm{T}$ lymphocytes in CML might existed in a unusually activated state leading to self injury.

Besides HSCs, there also existed another kind of stem cells called MSCs (Mesenchymal Stem Cells), they could differentiated into stroma cells and acted as the "niche" in the micro-environment[24]. MSCs also had the immunological regulation ability and were believed to be the "immune protection site" in the cells environment. So, we believed that MSCs might play important role in the pathogenesis of CML, but there was no article examined the immunological function of MSCs.

Previous studies[19,21] from our laboratory have identified Flk1 ${ }^{+}$(fetal liver kinase-1 positive) CD31 ${ }^{-} \mathrm{CD} 34^{-}$ cells carrying the $\mathrm{BCR} / \mathrm{ABL}$ fusion gene from the bone marrow of Philadelphia chromosome positive $\left(\mathrm{Ph}^{+}\right)$ patients with CML and found that these cells could differentiate into malignant blood cells and phenotypically defined endothelial cells at the single-cell level, suggesting these cells have the properties of hemangioblasts.
The main purpose of our article was to examine the immune characteristics of Flk $1^{+} \mathrm{CD} 31^{-} \mathrm{CD} 34^{-} \mathrm{MSC}$ in CML and analyse if there existed abnormalities comparing with the healthy donors.

\section{Patients, materials, and methods \\ Patient samples}

20 patients with newly diagnosed CML (12 male and 8 female, aged 17-63 years) were recruited in this study (table 1). All were $\mathrm{Ph}^{+}$patients with CML in chronic phase as revealed by bone marrow histology and cytogenetic analysis. The immunophenotypes of thawed cells were quite variable. None was treated with hydroxyurea or interferon before. The control samples were from 20 healthy donors (12 male and 8 female, aged 21-60 years). Bone marrow samples were collected after obtaining informed consent according to procedures approved by the Ethics Committee at the $309^{\text {th }}$ Hospital of Peoples Liberation Army.

\section{Cell preparations and culture}

Isolation and culture of bone marrow-derived CML hemangioblasts were performed as described previously with some modifications[19,21]. Briefly, mononuclear cells were separated by a Ficoll-Paque gradient centrifugation (specific gravity $1.077 \mathrm{~g} / \mathrm{mL}$; Nycomed Pharma AS, Oslo, Norway) and the sorted cells were plated at concentration of 1 cell/well by limiting dilution in a total of $96 \times 10$ wells coated with fibronectin (Sigma, St Louis, MO) and collagen (Sigma) for each patient. Culture medium was Dulbecco modified Eagle medium and Ham F12 medium (DF12) containing 40\% MCDB-201 medium complete with trace elements (MCDB) (Sigma), $2 \%$ fetal calf serum (FCS; Gibco Life Technologies,

Table 1 The general conditions of the patients

\begin{tabular}{ccccccc}
\hline Patient & Age & Sex & Diagonosis & Diagnosis time & Ph chromosome & Immunosuppressive therapy \\
\hline 1 & 84 & F & CML & Aug-04 & positive & yes \\
2 & 54 & M & CML & Jun-87 & positive & yes \\
3 & 56 & M & CML & May-99 & positive & yes \\
4 & 49 & M & CML & Feb-87 & positive & yes \\
5 & 66 & M & CML & Aug-04 & positive & yes \\
6 & 40 & F & CML & Feb-05 & positive & No \\
7 & 50 & F & CML & Sep-04 & positive & No \\
8 & 76 & F & CML & Aug-04 & positive & No \\
9 & 64 & F & CML & Dec-05 & positive & No \\
10 & 55 & M & CML & Apr-00 & positive & yes \\
11 & 49 & M & CML & Feb-05 & positive & No \\
12 & 51 & M & CML & Jun-01 & positive & yes \\
13 & 40 & F & CML & Dec-05 & positive & No \\
14 & 43 & $F$ & CML & Dec-05 & positive & No \\
15 & 60 & $M$ & CML & Nov-05 & positive & No \\
\hline
\end{tabular}

M: male; F:female; 
Paisley, United Kingdom), $1 \times$ insulin transferrin selenium (Gibco Life Technologies), $10^{-9} \mathrm{M}$ dexamethasone (Sigma), $10^{-4} \mathrm{M}$ ascorbic acid 2-phosphate (Sigma), 20 $\mathrm{ng} / \mathrm{mL}$ interleukin-6 (Sigma), $10 \mathrm{ng} / \mathrm{mL}$ epidermal growth factor (Sigma), $10 \mathrm{ng} / \mathrm{mL}$ platelet-derived growth factor BB (Sigma), $50 \mathrm{ng} / \mathrm{mL}$ fetal liver tyrosine kinase 3 (Flt-3) ligand (Sigma), $30 \mathrm{ng} / \mathrm{mL}$ bone morphogenetic protein-4 (Sigma), $100 \mathrm{U} / \mathrm{mL}$ penicillin and $100 \mathrm{ug} / \mathrm{mL}$ streptomycin (Gibco Life Technologies) at $37^{\circ} \mathrm{C}$ and a $5 \% \mathrm{CO}_{2}$ humidified atmosphere. Culture media were changed every 4 to 6 days.

\section{FISH analysis}

We cultured $\mathrm{BCR} / \mathrm{ABL}^{+}$hemangioblasts from male $\mathrm{CML}$ patients $(\mathrm{n}=12)$ and $\mathrm{Y}$ chromosome was detected using a probe (CEP Y Spectrum Red; Vysis, Downers Grove, IL) according to the manufacturer's instructions. Normal cells showed 2 red abl signals and 2 green bcr signals. BCR/ $\mathrm{ABL}^{+}$hemangioblasts showed a single red and a single green signal representing normal abl and bcr genes and the yellow signal representing fusion of $\mathrm{abl}$ and bcr genes.

\section{Fluorescence activated cell sorting (FACS)}

For immunophenotype analysis, expanded clonal cells were stained with antibodies against Flk1, CD29, CD31, CD34, CD44, CD45, CD105, (all from Becton Dickinson Immunocytometry Systems, Mountain View, CA). For intracellular antigen detection, cells were first fixed in $2 \%$ paraformaldehyde (Sigma) for 15 minutes at $4^{\circ} \mathrm{C}$ and permeabilized with $0.1 \%$ saponin (Sigma) for 1 hour at room temperature. Cells were washed and labeled with fluorescein isothiocyanate (FITC) conjugated secondary goat antimouse, goat antirabbit, or sheep antigoat antibodies (Sigma), then washed and analyzed using a FACS Calibur flow cytometer (Becton Dickinson, San Jose, CA).

\section{Mitogen proliferative assays}

Inmitogen proliferative assays, triplicate wells containing responder $1 \times 105 \mathrm{MNCs}$ were cultured with $50 \mathrm{~g} / \mathrm{ml}$ PHA (Roche, USA) in a total volume of $0.1 \mathrm{ml}$ medium at $37^{\circ} \mathrm{C}$ in $5 \% \mathrm{CO} 2$, and Flk1+CD31-CD34- MSCs were added on day 0 . Irradiated Flk1+CD31-CD34- MSCs (30 Gy) were cocultured with the MNCs at different ratios (MSCs to MNCs = 1:2, 1:10, 1:100). Control wells contained only MNCs. Cultures were pulsed with $1 \mathrm{Ci} /$ well [3H]-TdR (Shanghai Nucleus Research Institute, China) on day 2, and harvested $18 \mathrm{~h}$ laterwith a Tomtec (Wallac Inc., Gaithersburg, MD) automated harvester. Thymidine uptake was quantified using a liquid scintillation and luminescence counter (Wallac TRILUX).

\section{Mixed lymphocyte reaction assays (MLR)}

Blood mononuclear cells (MNCs) were prepared from normal volunteers' peripheral blood by Ficoll-Paque density gradient centrifugation and suspended inRPMI 1640 medium supplemented with $10 \%$ (vol/vol) FCS, 2 $\mathrm{mM}$ l-glutamine, $0.1 \mathrm{mM}$ nonessential amino acids (Life Technologies, Grand Island, NY), $1 \mathrm{mM}$ sodium pyruvate, $100 \mathrm{U} / \mathrm{mL}$ penicillin,

\section{Effect of MSCs on T cell cycle}

MSCs and MNCs were prepared as described before. T cells, stimulated with PHA (50 g/ml, final concentration) stimulation for 3 days, were cultured alone or cocultured with MSCs (derived from normal and MDS patient) or 3T3 cell line, then harvested and quantified. One million $\mathrm{T}$ cells were fixed with $70 \%$ cold ethanol at $4^{\circ} \mathrm{C}$ for $30 \mathrm{~min}$, washed with PBS twice, and stained with $50 \mathrm{~g} / \mathrm{ml}$ PI (Sigma, USA) at room temperature for $5 \mathrm{~min}$. Data were analyzed with Mod-FIT software.

\section{Effect of MSCs on T cell activation}

MSCs and MNCs were prepared as described before, respectively. $\mathrm{T}$ cells were cultured alone or cocultured with prepared MSCs and stimulated with PHA (50 g/ml final concentration). The expression of CD25 (BD, USA) and CD69 (BD, USA) was detected by flow cytometry at $24 \mathrm{~h}$, and CD44 (BD, USA) was detected at $72 \mathrm{~h}$.

\section{Effect of MSCs on T cell apoptosis}

MSCs and MNCs were prepared as described before. T cells were cultured alone or cocultured withMSCs with PHA (50 g/ml final concentration) stimulation for 3 days, then harvested and quantified, stained with Annexin-V kit (BD, USA), and analyzed by flow cytometry (FACS Vantage).

\section{RNA-i experiments}

The si-RNA sequence targeting human MMP-9 (from mRNA sequence; Invitrogen online) corresponds to the coding region 377-403 relative to the first nucleotide of the start codon (target $=5^{\prime}$-AAC ATC ACC TAT TGG ATC CAA ACT AC-3'). Computer analysis using the software developed by Ambion Inc. confirmed this sequence to be a good target. si-RNAs were 21 nucleotides long with symmetric 2-nucleotide 3'overhangs composed of 2'-deoxythymidine to enhance nuclease resistance. The si-RNAs were synthesized chemically and high pressure liquid chromatography purified (Genset, Paris, France). Sense si-RNA sequence was 5'-CAU CAC CUA UUG GAU CCA AdT dT-3'. Antisense siRNA was 5'-UUG GAU CCA AUA GGU GAU GdT dT-3'. For annealing of si-RNAs, mixture of complementary single stranded RNAs (at equimolar concentration) was incubated in annealing buffer $(20 \mathrm{mM}$ Tris- $\mathrm{HCl} \mathrm{pH} \mathrm{7.5,} 50 \mathrm{mM} \mathrm{NaCl}$, and $10 \mathrm{mM} \mathrm{MgCl}_{2}$ ) for 2 minutes at $95^{\circ} \mathrm{C}$ followed by a slow cooling to room temperature (at least $25^{\circ} \mathrm{C}$ ) and then proceeded to 
storage temperature of $4^{\circ} \mathrm{C}$. Before transfection, cells cultured at $50 \%$ confluence in 6 -well plates $\left(10 \mathrm{~cm}^{2}\right)$ were washed two times with OPTIMEM 1 (Invitrogen) without FCS and incubated in $1.5 \mathrm{ml}$ of this medium without FCS for 1 hour. Then, cells were transfected with MMP-9-RNA duplex formulated into Mirus Tran$s \mathrm{TT}-\mathrm{TKO}$ transfection reagent (Mirus Corp, Interchim, France) according to the manufacturer's instructions. Unless otherwise described, transfection used $20 \mathrm{nM}$ RNA duplex in $0.5 \mathrm{ml}$ of transfection medium OPTIMEM 1 without FCS per $5 \times 10^{5}$ cells for 6 hours and then the medium volume was adjusted to $1.5 \mathrm{ml}$ per well with RPMI 2\% FCS. SilencerTM negative control 1 si-RNA (Ambion Inc.) was used as negative control under similar conditions (20 nM). The efficiency of silencing is $80 \%$ in our assay.

\section{Enzyme-linked Immunoadsorbent Assays}

This was carried out according to the manufacturer's recommendations (Oncogene Research Products). Results were compared with those obtained with serially diluted solutions of commercially purified controls. Anti-human cytokine antibodies (R\&D Systems, Minneapolis, MN) was added at $0.4 \mathrm{ug} / \mathrm{ml}$ in $0.05 \mathrm{M}$ bicarbonate buffer ( $\mathrm{pH}$ 9.3) to 96-well, U-bottom, polyvinyl microplates (Becton Dickinson and Co., Oxnard, CA) and the cell number was $1 \times 10^{5} / 100$ ul. After incubation overnight at $4{ }^{\circ} \mathrm{C}$, the plates were washed and blocked with $1 \%$ gelatin for 1 hour. Samples (50 ul) or standard protein diluted in $0.5 \%$ gelatin were added to the wells. After incubation for 1 hour at $37^{\circ} \mathrm{C}$, the plates were washed again, and $50 \mathrm{ng} / \mathrm{ml}$ biotinylated antimouse antibody (R\&D Systems) was added for 1 hour at $37^{\circ} \mathrm{C}$. The plates were then washed and incubated with streptavidin-HRP for 1 hour at $37^{\circ} \mathrm{C}$. After washing, $0.2 \mathrm{mM}$ ABTS (Sigma Chemical Co.) was added to the wells, and after 10 minutes, the colorimetric reaction was measured at $405 \mathrm{~nm}$ with an ELISA reader VERSAmax (Molecular Devices, Sunnyvale, CA).

\section{Western blot}

CML hemangioblasts were harvested at specific times after treatment with regents as indicated in each experiment. Cells were mixed with loading buffer and subject to electrophoresis. After electrophoresis, proteins were transferred to polyvinyl difluoride membranes (Pall Filtron) using a semidry blotting apparatus (Pharmacia) and probed with mouse mAbs, followed by incubation with peroxidase-labeled secondary antibodies. Detection was performed by the use of a chemiluminescence system (Amersham) according to the manufacturer's instructions. Then membrane was striped with elution buffer and reprobed with antibodies against the nonphosphorylated protein as a measure of loading control.
Controls for the immnoprecipitation used the same procedure, except agarose beads contained only mouse IgG.

\section{Statistics}

Statistical analysis was performed with the statistical SPSS 13.0 software. The paired-sample t-testwas used to test the probability of significant differences between samples. Statistical significance was defined as $\mathrm{p}<0.05$.

\section{Results}

\section{The biological characteristics of CML hemangioblasts}

To establish the characteristics of CML hemangioblasts, we first examined the morphology, phenotype and growth patterns of them respectively. Results showed that they persistently displayed fibroblast-like morphology (Figure 1A) and CML specific BCR/ABL oncogene was observed by FISH analysis (Figure 1B) and PCR (Figure $1 \mathrm{C}$ ) in CML hemangioblasts. Isotype analysis indicated they were all persistently negative for CD34 and CD31 but positive for Flk1, CD29, CD44 and CD105 (Figure 1D).

\section{Immunomodulatory decrease on T cell proliferation}

To analyse immunomodulatory effects on $\mathrm{T}$ cell proliferation, irradiated MSCs were added to mitogen-stimulated $\mathrm{T}$ cell proliferation reactions and mixed lymphocyte reactions (MLR). A previous study showed that MSCs from healthy volunteers could obviously inhibit the proliferation of $\mathrm{T}$ cells not only stimulated with mitogen but also in MLR. Additionally, this inhibitory effect occurred in a dose-dependent manner. In mitogen-stimulated $\mathrm{T}$ cell proliferation assays, the proliferation of $\mathrm{T}$ cells at 1:2 ratio (MSCs to MNCs) was significantly inhibited to about $1 \%$ with normal MSCs, but proliferation at the same ratiowas inhibited only to about 37\% with CML-derived MSCs (compared with coculture system of normal MSCs, p < 0.05). Similarly, inhibitory rates were impaired at 1:10 ratio (MSCs to MNCs) in CML-derived MSCs (compared with co-culture system of normal MSCs, $\mathrm{p}<0.05$ ). Also the inhibitory effect was dose dependent in CML-derived MSCs. (Figure 2A). In MLR, a similar impaired inhibitory effect with MDS-derived MSCs was observed. (Figure 2B)

\section{Immunomodulatory attenuation of MSCs on T cell cycle} A previous study showed that MSCs could silence T cells in G0/G1 phase, which might be one of the possible mechanisms of MSC's inhibitory effect on T cells. When the inhibitory effect of CML-derived MSC on T cell proliferation was impaired, the related inhibitory effect on cell cycle was analyzed. In a PHA-stimulating system without MSC co-culture, there were $67.3 \pm 3.7 \%$ and $28.4 \pm 2.9 \% \mathrm{~T}$ cells in G0/G1 phase and $\mathrm{S}$ phase, respectively. When normal MSCs were present in co- 


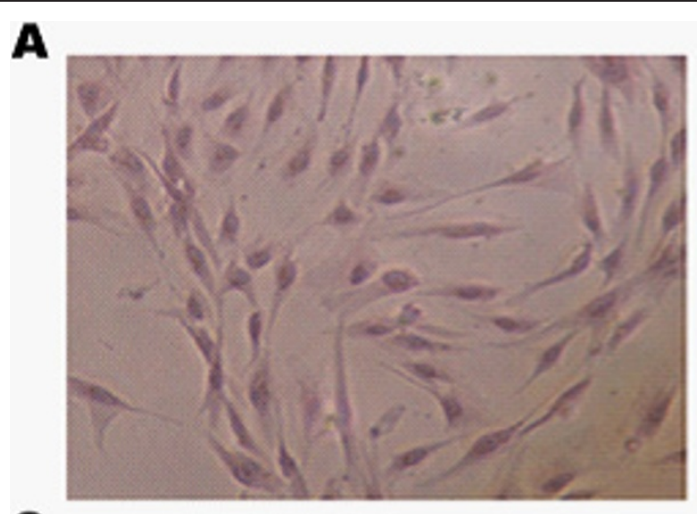

B
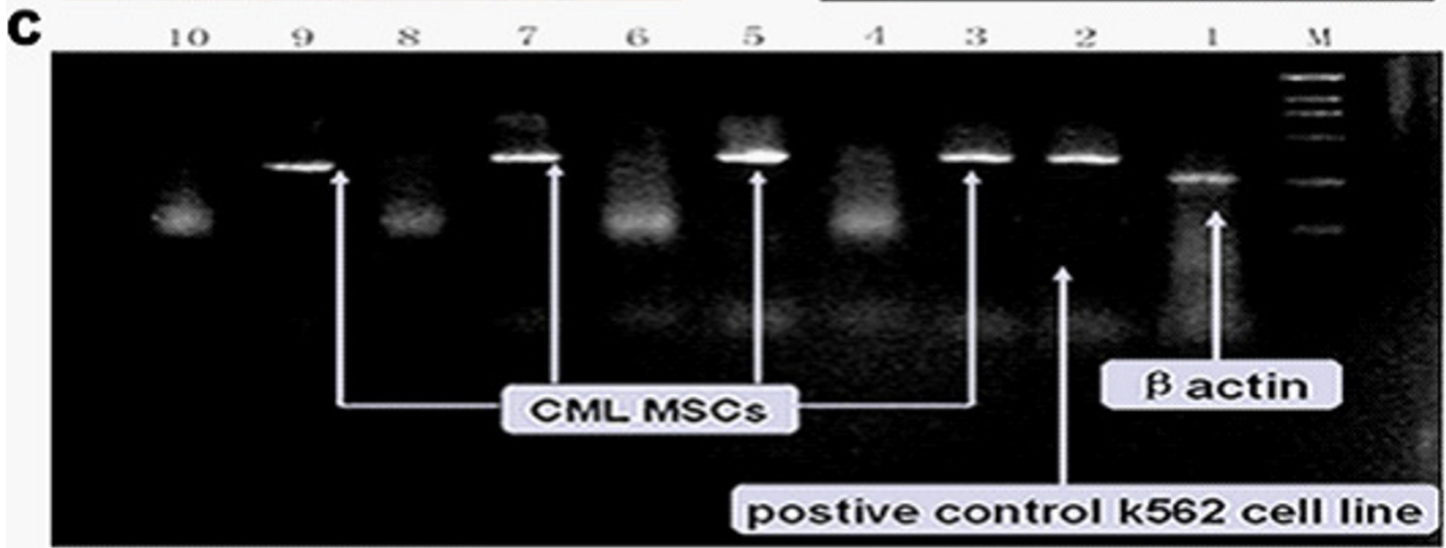

D
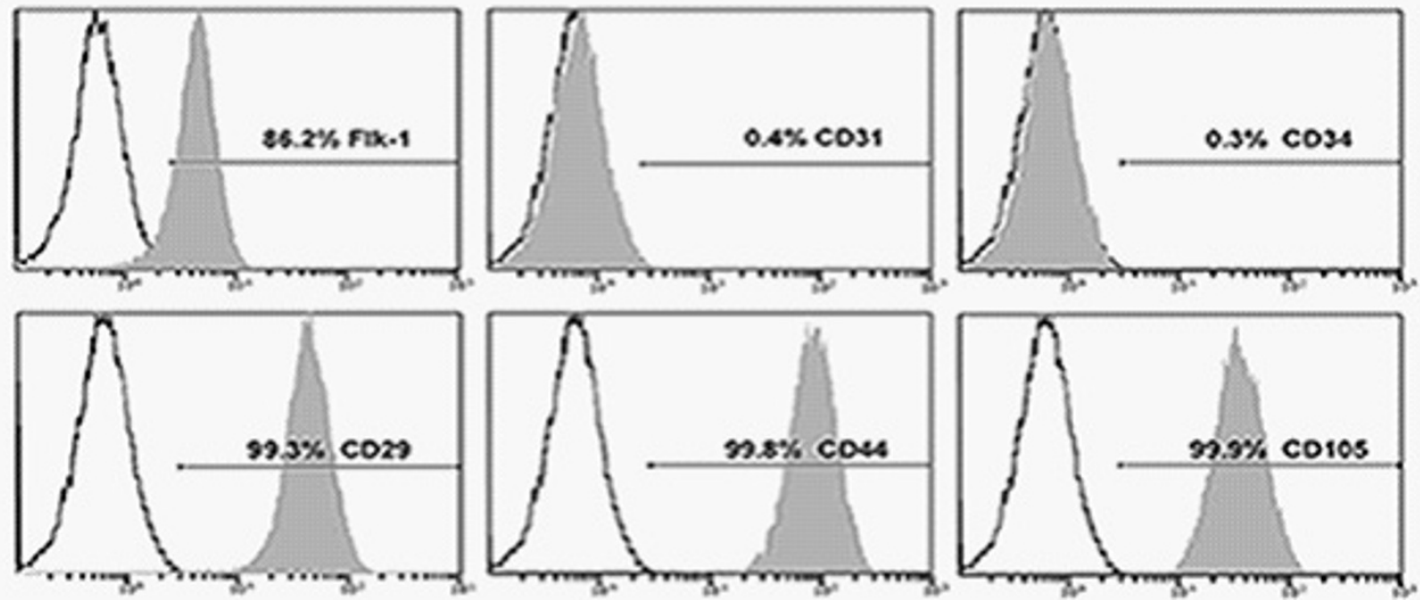

Figure 1 Biological characteristics of the CML MSCs. (A) The morphology of hemangioblasts from CML (Magnification $\times 200)$. (B) BCR/ABL fusion gene was detected by FISH (yellow signal is the positive one) in CML hemangioblasts from male patients. (C) BCR/ABL fusion gene was detected by RT-PCR(line4,6,8,10 correspond to non-special amplification).(D) Isotype analysis showed they were all persistently negative for CD34 and CD31 but positive for Flk1, CD29, CD44 and CD105.

culture, the percentages of $\mathrm{T}$ cells in G0/G1 phase and S phase were $94.0 \pm 1.9 \%$ and $3.1 \pm 1.9 \%$, respectively (compared with PHA stimulated T cells, $\mathrm{p}<0.05$ ). MSCs from healthy volunteers could have most of their $\mathrm{T}$ cells in G0/G1 phase with fewer cells entering $\mathrm{S}$ phase. However, T cells in G0/G1 phase and S phase remained $74.5 \pm 1.2 \%$ and $22.1 \pm 2.4 \%$ in the co-culture system of CML-derived MSCs (compared with co-culture system of normal MSCs, $\mathrm{p}<0.05)$. This result was confirmed by five independent tests (Figure 3). The 3T3 cell line was used as a control, and no effects on cell cycle were observed $(70.3 \pm 3.1 \%$ in G0/G1 and $27.3 \pm$ $5.1 \%$ in S, respectively (compared with PHA stimulated $\mathrm{T}$ cells, $\mathrm{p}>0.05)$. These results suggested that the 


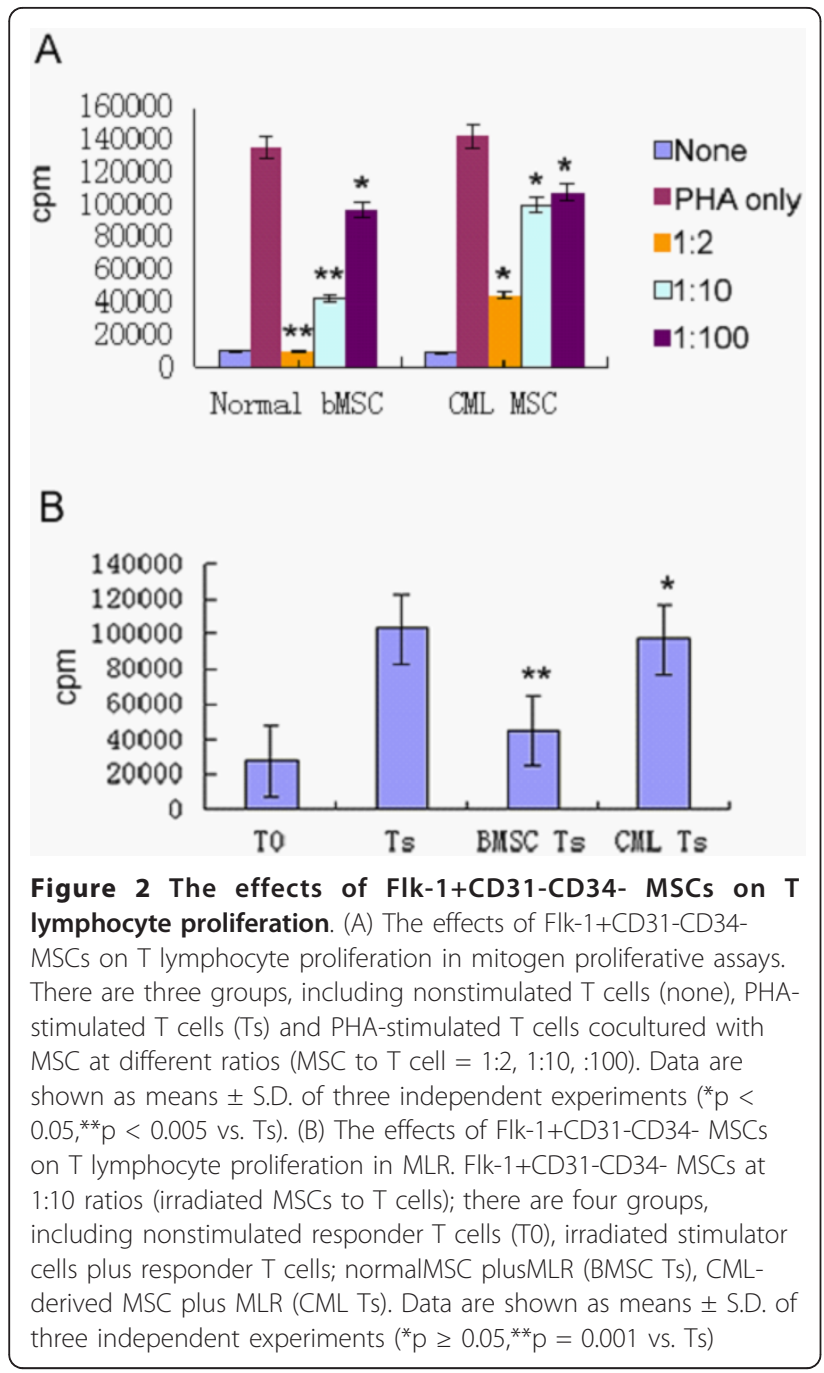

inhibitory effect of CML-derived MSCs on cell cycle arrest was also impaired.

\section{Impaired effects of MSCs on T cell activation}

MSCs from CML patients could significantly inhibit activation of $\mathrm{T}$ cells. The percentage of CD25, CD69 and CD44 in PHA induced T lymphocyte was $12.3 \pm 3.5 \%$, $34.5 \pm 5.9 \%$ and $29.4 \pm 7.0 \%$ respectively. But they were $3.1 \pm 2.3 \%, 6.4 \pm 3.2 \%$ and $2.1 \pm 1.7 \%$ when co-cultured with normal hemangioblasts and, when co-cultured with CML hemangioblasts, they were $5.4 \pm 2.3 \%, 31.5 \pm 6.8 \%$ and $24.5 \pm 3.6 \%$ respectively. All data presented here were confirmed by repeated tests (Figure 4). These results also indicated that MSCs from CML patients were impaired in their immuno-modulatory function.

\section{Dampening effect of MSCs on T cell apoptosis}

In apoptosis tests, we have observed that MSCs from healthy volunteers could significantly dampen the effect

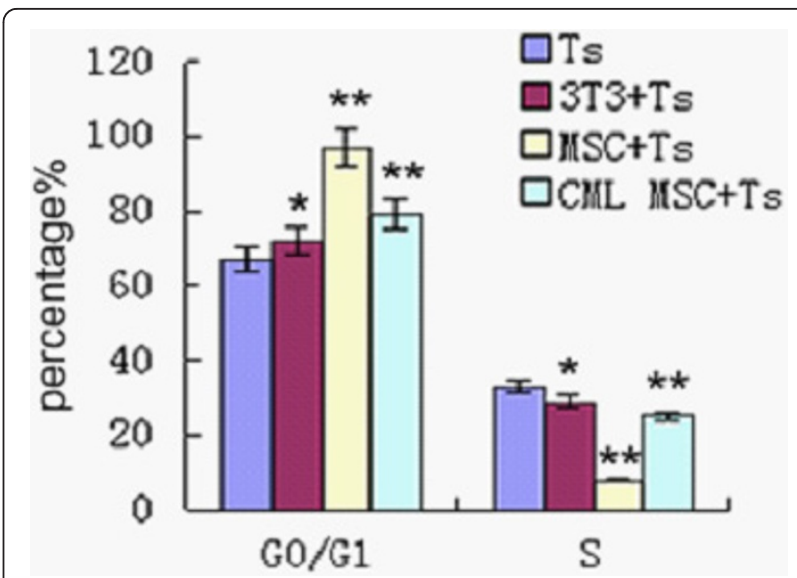

Figure 3 Effects ofMSCs on T cell cycle. Flk-1+CD31-CD34- MSCs or $3 T 3$ at 1:10 ratios (MSCs to T cells); the data are expressed as mean \pm S.D. Of triplicates of five separate experiments with similar results. Cell cycles of PHA-stimulated T cells were analyzed in T cells alone (Ts), cocultured with MSCs (MSC + Ts) group andMSCs derived from CML patient group (CML MSC + Ts). $3 T 3$ cell line was used as control $(3 T 3+T s)$. Data are shown as means \pm S.D. of five independent experiments $\left({ }^{*} p \geq 0.05\right.$, ${ }^{* *} p<0.05$ vs. Ts)

of activation-induced apoptosis of $\mathrm{T}$ cells. Following stimulation with PHA for 3 days, the rate of apoptosis of $\mathrm{T}$ cells was $23.37 \pm 2.71 \%$. When PHA-stimulated $\mathrm{T}$ cells were cocultured with MSCs obtained from healthy volunteers, the percentage of apoptotic $\mathrm{T}$ cells decreased to $14.1 \pm 0.65 \%$ (compared with PHA stimulated T cells, $\mathrm{p}<0.05)$. In the same condition, the apoptosis percentage of $\mathrm{T}$ cells co-cultured with MDS-derived MSCs further decreased to $8.36 \pm 1.31 \%$ (compared with coculture systemof normalMSCs, $\mathrm{p}<0.05)$. We repeated the experiment five times to confirm this result (Figure 5). These results suggested the dampening effect of CML-derived MSCs on activation-induced T apoptosis seemed to be enhanced.

\section{Efficient extinction of MMP-9 expression in HT1080 cells by RNAi strategy and the concomitantly upregulation of s-ICAM-1}

We used an RNAi method to target MMP-9 in the CML MSC and the constructs we designed encoded an RNA that targets the MMP-9 mRNA. The target sequence had no homology with other members of the MMP family. The ds-RNA and Silencer negative control si-RNA (snc) were each tested for their ability to suppress MMP-9 specifically. We first assessed whether RNAi was dose and time-dependent. A MMP-9 dependent ds-RNA-mediated inhibition was observed in a dose and time dependent manner (Figure 6A). The time-course assay performed with $20 \mathrm{nM}$ ds-RNA-transfected CML MSC showed that the induced MMP-9 silencing could be maintained for at least 3 days (Figure 


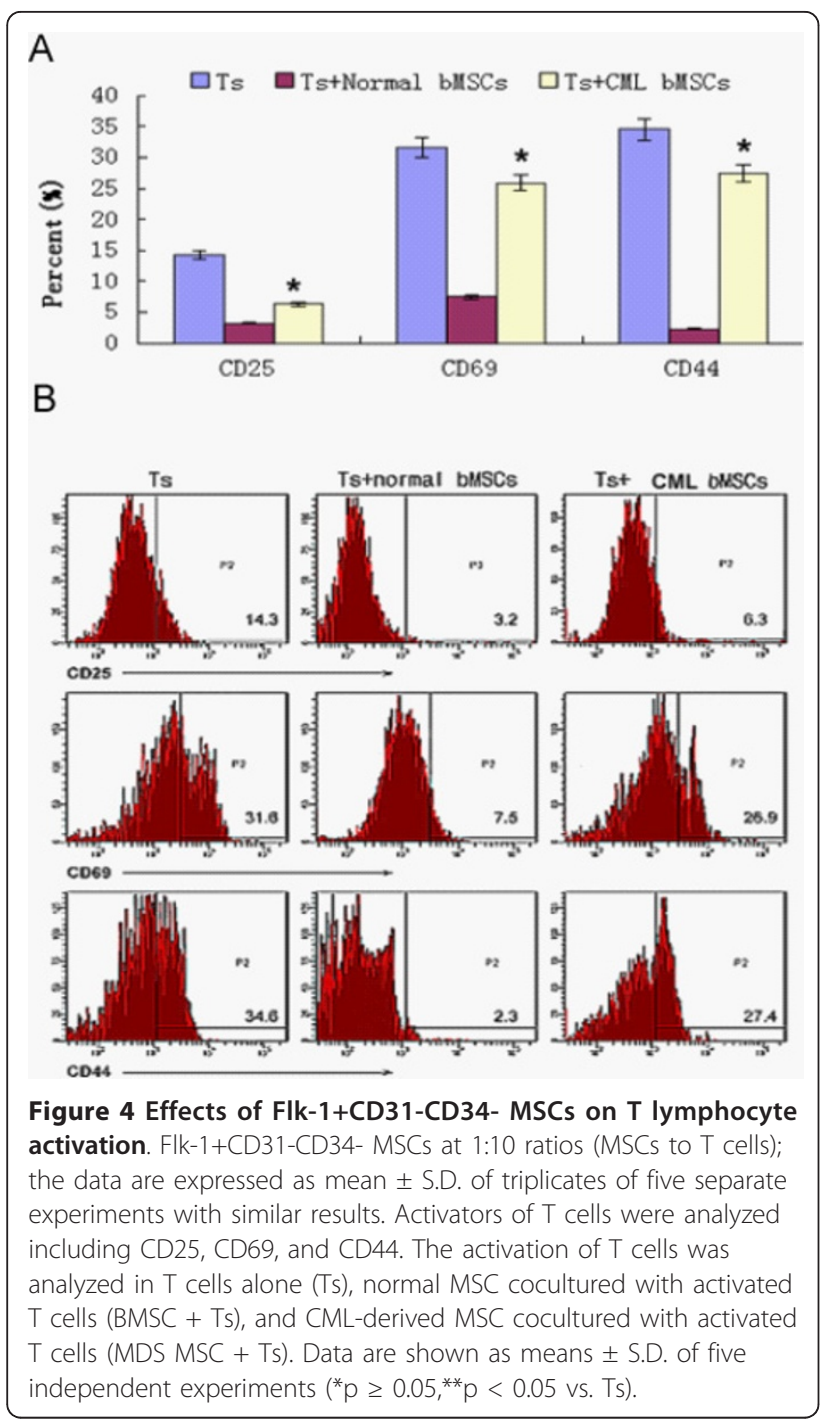

6B). Besides, serum ICAM-1 was concomitantly changing with MMP-9. The Western blotting results were confirmed by enzyme-linked immunoadsorbent assay. CML snc-RNA-transfected cells cultured up to 3 days spontaneously released high amount of MMP-9 into the culture conditioned medium whereas ds-RNA-transfected cells showed a marked time- and dose- dependent inhibition in MMP-9 protein levels. Importantly, levels of s-ICAM-1 were also affected with ds-RNA transfection (Figure 6C).

\section{Discussion}

MSC isolated from different tissues had immune regulation ability not only in vivo but in vitro and it might consist the "immune protection site" in human body $[25,26]$. Considering their richness in source, availability for expansion, and most importantly, their robust immuno-modulatory activity, MSCs appear to be a

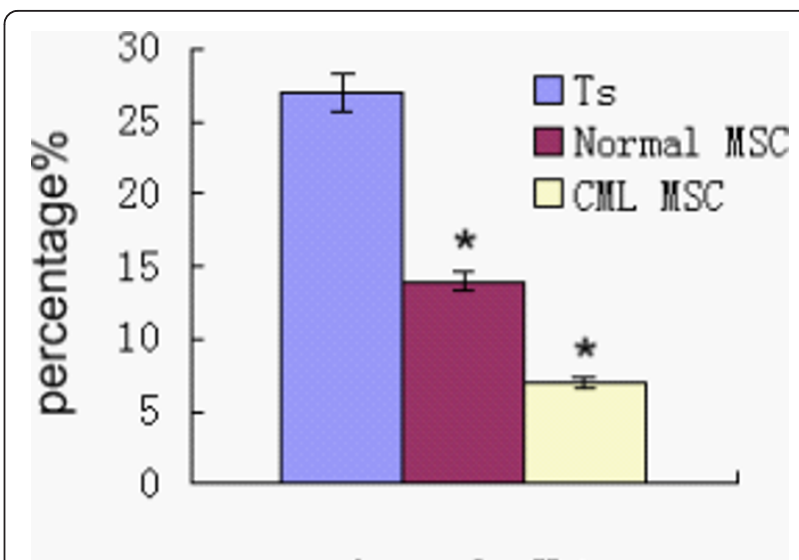

Annexin V +

Figure $\mathbf{5}$ Effect of MSCs on T cell apoptosis. Flk-1+CD31-CD34MSCs at 1:10 ratios (MSCs to T cells); the data are expressed as mean \pm S.D. of triplicates of five separate experiments with similar results. The test was conducted by Annexin-V and PI double staining and analyzed by flow cytometry. Apoptosis of T cells was analyzed in T cells alone (Ts), normalMSC cocultured with activated T cells (MSC $+\mathrm{Ts}$ ), and CML patient-derived MSC cocultured with activatedT cells (CMLMSC + Ts). Annexin V+means the cells were PI negative and Annexin $V$ positive. Data are shown as means \pm S.D. of five independent experiments ( ${ }^{*} p<0.05$ vs. Ts).

primary candidate for cellular therapy in immune disorders $[12,16,27]$. In normal physiological conditions, MSCs are very scarce (one MSC per 10,000$100,000 \mathrm{MNC})$, therefore, normal immune responses against foreign antigens are not affected. This is consistent with in vitro results showing that immuno-suppressive function was abolished when the ratio of MSC to T cells was less than 1:100. However, once a large number of MSCs were infused for immune therapy, influx of MSC in the circulation and bone marrow could bring the hypersensitive immune response to normal. Moreover, MSC infusion could not only modulate immune responses but enhance the hematopoietic microenvironment. Transplantation of MSCs offers bright prospects in developing new therapies for blood diseases caused by an abnormal immune system and impaired hematopoietic microenvironment. To date, MSCs have been used to treat GVHD, which is a disorder of hyperimmunoresponse, and shown to be effective clinically $[28,29]$.

Chronic myeloid leukemia is a clonal hematopoietic stem cell disorder characterized by the $t(9 ; 22)$ chromosome translocation and resultant production of the constitutively activated $B C R / A B L$ tyrosine kinase[30]. Interestingly, this $\mathrm{BCR} / \mathrm{ABL}$ fusion gene, was also detected in the endothelial cells of patients with CML, suggesting that CML might originate from hemangioblastic progenitor cells that can give rise to both blood cells and endothelial cells. Although Interferon- $\alpha$, 


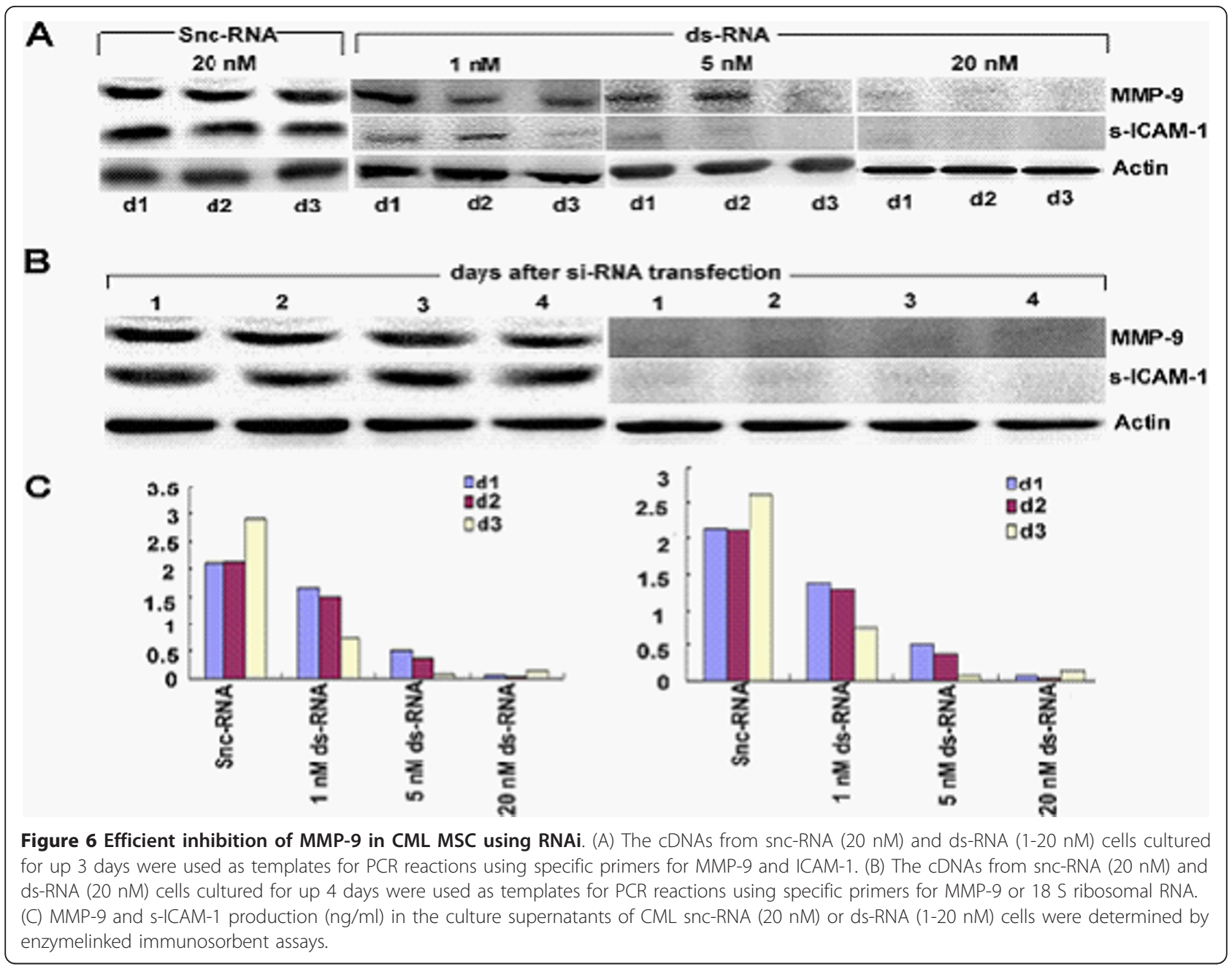

Intimab(a $B C R / A B L$ tyrosine kinase inhibitor) and stem cell transplantations are the standard therapeutic options, transplant-related morbidity from graft-versushost disease and mortality rates of $10 \%$ to $20 \%$ have greatly reduced the allogeneic hematopoietic cell transplantation in clinics[31], while interferon- $\alpha$ is only effective in some patients to some degree and chemotherapeutic intervention does not result in prolonged overall survival[32,33] and the reason is possibly due to some unknown biology of the CML immune regulation[34].

We conducted this study of CML patient-derived MSCs to evaluate the safety and effectiveness of autologous MSCs in treating CML. We tested the karyotype and genetic changes of in vitro-expanded MSCs for safety evaluation. The immuno-modulatory function of MSCs was also examined. The investigation of CML patient-derived MSCs could help to further elucidate etiology and pathology of CML. Specifically, the answers to questions of whether gene aberrations exist in MSCs and whether the functions of MSCs are impaired are crucial for understanding of CML development and finding effective treatments.

We utilised Flk1+CD31-CD34- MSCs from CML patients for 4-6 passages, and there were chromosomal abnormities, indicating that mutation of CML happened at the hematoangioblast level[35]. We thereby hypothesized that malignant mutation existed in stem cells more primordial than HSCs. Data from functional tests proved that CML-derived MSCs had abnormal immuno-modulatory function, although their MSCs showed normal karyotype. An inhibitory effect on T cell proliferation is an important characteristic of MSC in immuno-modulatory action. A previous study, in accordance with another report, suggested that the inhibitory effect on $\mathrm{T}$ cell proliferation might be through cell cycle arrest. MSCs from healthy volunteers could obviously block $\mathrm{T}$ cells in G0/G1 phase. In this study, inhibitory effects of MDS-derived MSCs on T cell proliferation were obviously impaired. Moreover, no significant cell 
cycle arrest was observed in PHA-stimulated T cells cocultured with CML-derived MSCs. In addition, an inhibitory effect on $\mathrm{T}$ cell activation is another key point of immuno-modulatory function for MSCs, although there are still disputes[21,22]. CD25, CD69 and CD44 are candidates for $\mathrm{T}$ cell activation in different phases. In our study, MSCs from healthy volunteers showed significant inhibitory effects on expression of $\mathrm{T}$ cell activation markers, but MSCs from CML patients showed very limited inhibitory effects. These results suggested that CML-derived MSCs have immunologic abnormalities and their application in immuno-modulation might be limited.

Normally, the invasion and metastasis by malignant tumor cells consists of three major steps: the receptormediated adhesion of tumor cells to the extracellular matrix, the degradation of the extracellular matrix by the proteinase secreted by the tumor cells, and the transfer and proliferation of tumor cells[36]. So, the loose of ECM and secreted cytokines are important for the metastasis of the tumor cells from the primary tumor[37]. Pathological conditions will change the tumor cell fate leading to invasion and metastasis[38], Local secretion of proteases have been implicated in this tumor-stroma crosstalk. Matrix Metalloproteinase-9 (MMP-9) is one of them which has the preferential ability to degrade denatured collagens (gelatin) and collagen type IV, the 2 main components of basement membranes and therefore plays a critical role in tumour progression and metastaisis[39]. Moreover, its expression increases with the increased or greater proliferation of tumor cells.

We used a ds-RNA to interfere with the expression of MMP-9 gene in CML MSC and our findings support the conclusion that MMP-9 constitutes a trigger for the switch between adhesive and invasive states in CML MSC by changing the ICAM-1 from membraneanchored state to solvable one leading to tumor cell immune evasion and metastasis.

In conclusion, the immune function of CML patientderived MSCs showed that their immuno-modulatory ability, compared to MSCs from healthy volunteers, was impaired, whichmight be a cause for an abnormal hematopoietic environment. This indicates that autologous MSCs transplantation might be futile. Instead, allogenic MSCs transplantation might be a better choice to ameliorate CML.

\section{Acknowledgements}

Supported by grants from the "863 Projects" of Ministry of Science and Technology of PR China (No. 2006AA02A109. 2006AA02A115); National Natural Science Foundation of China (No.30570771; Beijing Ministry of Science and Technology (No. D07050701350701) and Cheung Kong Scholars programme.

\section{Authors' contributions}

$\mathrm{ZH}$ carried out the molecular genetic studies, participated in the sequence alignment and drafted the manuscript. AG carried out the immunoassays. SY participated in the design of the study and performed the statistical analysis. All authors read and approved the final manuscript.

\section{Competing interests}

The authors declare that they have no competing interests.

Received: 23 September 2010 Accepted: 2 May 2011

Published: 2 May 2011

\section{References}

1. Barnes DJ, Melo JV: Primitive, quiescent and difficult to kill: the role of non-proliferating stem cells in chronic myeloid leukemia. Cell Cycle 2006, 5:2862-2866.

2. Jørgensen HG, Allan EK, Jordanides NE, Mountford JC, Holyoake TL: Nilotinib exerts equipotent antiproliferative effects to Imatinib and does not induce apoptosis in CD34+CML cells. Blood 2007, 109:4016-4019.

3. Jørgensen HG, Copland M, Allan EK, Jiang X, Eaves A, Eaves C, Holyoake TL: Intermittent exposure of primitive quiescent chronic myeloid leukemia cells to granulocyte-colony stimulating factor in vitro promotes their elimination by Imatinib mesylate. Clin Cancer Res 2006, 12:626-633.

4. Ries C, Pitsch T, Mentele R, Zahler S, Egea V, Nagase H, Jochum M: Identification of a novel $82 \mathrm{kDa}$ proMMP-9 species associated with the surface of leukaemic cells: (auto-)catalytic activation and resistance to inhibition by TIMP-1. Biochem J 2007, 405(3):547-58.

5. Yu Q, Stamenkovic I: Cell surface-localized matrix metalloproteinase-9 proteolytically activates TGF- $\beta$ and promotes tumor invasion and angiogenesis. Genes Dev 2000, 14:163-176.

6. Fridman R, Toth M, Chvyrkova I, Meroueh S, Mobashery S: Cell surface association of matrix metalloproteinase-9 (gelatinase B). Cancer Metastasis Rev 2003, 22:153-166.

7. Stefanidakis $M$, Koivunen E: Cell-surface association between matrix metalloproteinases and integrins: role of the complexes in leukocyte migration and cancer progression. Blood 2006, 108:1441-1450.

8. Baran $Y$, Ural AU, Gunduz U: Mechanisms of cellular resistance to imatinib in human chronic myeloid leukemia cells. Hematology 2007, 12(6):497-503.

9. Kim JG, Sohn SK, Kim DH, Baek JH, Lee NY, Suh JS: Clinical implications of angiogenic factors in patients with acute or chronic leukemia: hepatocyte growth factor levels have prognostic impact, especially in patients with acute myeloid leukemia. Leuk Lymphoma 2005, 46(6):885-91.

10. Kaneta Y, Kagami Y, Tsunoda T, Ohno R, Nakamura Y, Katagiri T: Genomewide analysis of gene-expression profiles in chronic myeloid leukemia cells using a cDNA microarray. Int J Oncol 2003, 23(3):681-91.

11. Bruchova $H$, Borovanova $T$, Klamova $H$, Brdicka R: Gene expression profiling in chronic myeloid leukemia patients treated with hydroxyurea. Leuk Lymphoma 2002, 43(6):1289-95.

12. Janowska-Wieczorek A, Majka M, Marquez-Curtis L, Wertheim JA, Turner AR, Ratajczak MZ: Bcr-abl-positive cells secrete angiogenic factors including matrix metalloproteinases and stimulate angiogenesis in vivo in Matrige implants. Leukemia 2002, 16(6):1160-6.

13. Narla RK, Dong Y, Klis D, Uckun FM: Bis(4,7-dimethyl-1, 10-phenanthroline) sulfatooxovanadium(I.V.) as a novel antileukemic agent with matrix metalloproteinase inhibitory activity. Clin Cancer Res 2001, 7(4):1094-101.

14. Sun X, Li Y, Yu W, Wang B, Tao Y, Dai Z: MT1-MMP as a downstream target of $B C R-A B L / A B L$ interactor 1 signaling: polarized distribution and

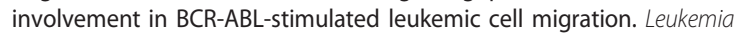
2008, 22(5):1053-6.

15. Ries C, Loher F, Zang C, Ismair MG, Petrides PE: Matrix metalloproteinase production by bone marrow mononuclear cells from normal individuals and patients with acute and chronic myeloid leukemia or myelodysplastic syndromes. Clin Cancer Res 1999, 5(5):1115-24.

16. Kaneta Y, Kagami Y, Tsunoda T, Ohno R, Nakamura Y, Katagiri T: Genomewide analysis of gene-expression profiles in chronic myeloid leukemia cells using a cDNA microarray. Int J Oncol 2003, 23(3):681-91.

17. Sang-Oh Yoon, Sejeong Shin, Ho-Jae Lee: Isoginkgetin inhibits tumor cell invasion by regulating phosphatidylinosito 3 kinase/Akt dependent matrix metalloproteinase-9 expression. Mol Cancer Ther 2006, 5(11):344-349. 
18. Anand P, Sundaram C, Jhurani S, Kunnumakkara AB, Aggarwal BB: Curcumin and cancer: an "old-age" disease with an "age-old" solution. Cancer Lett 2008, 267(1):133-64

19. Fang Baijun, Zheng Chunmei, Liao Lianming, Shi Mingxia, Yang Shaoguang, Zhao RCH: Identification of Human Chronic Myelogenous Leukemia Progenitor Cells with Hemangioblastic Characteristics. Blood 2005, 105(7):2733-40.

20. Reyes M, Lund T, Lenvik T, Aguiar D, Koodie L, Verfaillie CM: Purification and ex vivo expansion of postnatal human marrow mesodermal progenitor cells. Blood 2001, 98:2615-25.

21. Guo H, Fang B, Zhao RC: Hemangioblastic characteristics of fetal bone marrow-derived Flk1(+)CD31(-)CD34(-) cells. Exp Hematol 2003, 31:650-613.

22. Yunbiao Lu, Larry M: Wahl. Production of matrix metalloproteinase-9 by activated human monocytes involves a phosphatidylinositol-3 kinase/ Akt/IKK/NF-KB pathway. J Leuk Bio 2005, 78:259-65.

23. Gustin JA, Ozes ON, Akca H, Pincheira R, Mayo LD, Li Q, Guzman JR, Korgaonkar CK, Donner DB: Cell type-specific expression of the IKB kinases determines the significance of phosphati-dylinositol 3-kinase/Akt signaling to NF-KB activation. J Biol Chem 2004, 279:1615-1620.

24. Palamà IE, Leporatti S, de Luca E, Di Renzo N, Maffia M, GambacortiPasserini C, Rinaldi R, Gigli G, Cingolani R, Coluccia AM: Imatinib-loaded polyelectrolyte microcapsules for sustained targeting of $B C R-A B L+$ leukemia stem cells. Nanomedicine (Lond) 2010, 5(3):419-31.

25. Karanes C, Nelson GO, Chitphakdithai P, Agura E, Ballen KK, Bolan CD, Porter DL, Uberti JP, King RJ, Confer DL: Twenty years of unrelated donor hematopoietic cell transplantation for adult recipients facilitated by the National Marrow Donor Program. Biol Blood Marrow Transplant 2008, 14(9 Suppl):8-15, 9 .

26. Martin MG, Dipersio JF, Uy GL: Management of the advanced phases of chronic myelogenous leukemia in the era of tyrosine kinase inhibitors. Leuk Lymphoma 2008, 29:1-10.

27. Martinelli G, Soverini S, lacobucci I, Baccarani M: Intermittent targeting as a tool to minimize toxicity of tyrosine kinase inhibitor therapy. Nat Clin Pract Oncol 2009, 6(2):68-9.

28. Catriona H, Jamieson Y: Chronic myeloid leukemia stem cell. Hematology Am Soc Hematol Educ Program 2008, 34:436-42.

29. Pelletier SD, Hong DS, Hu Y, Liu Y, Li S: Lack of the adhesion molecules Pselectin and intercellular adhesion molecule-1 accelerate the development of BCR/ABL-induced chronic myeloid leukemia-like myeloproliferative disease in mice. Blood 2004, 104:2163-2171.

30. Martin-Henao GA, Quiroga R, Sureda A, González JR, Moreno V, García J: Lselectin expression is low on CD34+ cells from patients with chronic myeloid leukemia and interferon-a up-regulates this expression. Haematologica 2000, 85:139-146.

31. Wertheim JA, Forsythe K, Druker BJ, Hammer D, Boettiger D, Pear WS: BCR$\mathrm{ABL}$-induced adhesion defects are tyrosine kinase-independent. Blood 2002, 99(11):4122-4130.

32. Fiore Emilio, Fusco Carlo, Romero Pedro: Matrix metalloproteinase 9 (MMP-/gelatinase B) proteolytically cleaves ICAM-1 and participates in tumor cell resistance to natural killer cell-mediated cytotoxicity. Oncogene 2002, 21:5213-5223.

33. Darai E, Stefanidakis M, Koivunen E: Cell-surface association between matrix metalloproteinases and integrins: role of the complexes in leukocyte migration and cancer progression. Blood 2006, 108:1441-1450.

34. Molica S, Vitelli G, Levato D, Giannarelli D, Vacca A, Cuneo A, Cavazzini F, Squillace R, Mirabelli R, Digiesi G: Increased serum levels of matrix metalloproteinase- 9 predict clinical utcome of patients with early B-cell chronic lymphocytic leukemia. European Journal of Haematology 2003, 10:373-378.

35. Kamiguti AS, Lee ES, Till KJ, Harris RJ, Glenn MA, Lin K, Chen HJ, Zuzel M, Cawley JC: The role of matrix metalloproteinase 9 in the pathogenesis of chronic lymphocytic leukaemia. Br J Haematol 2004, 125:128-140.

36. Møller GM, Frost V, Melo JV, Chantry A: Upregulation of the TGFbeta signalling pathway by Bcr-Abl: implications for haemopoietic cell growth and chronic myeloid leukaemia. FEBS Lett 2007, 581(7):1329-34.

37. Atfi A, Abécassis L, Bourgeade MF: Bcr-Abl activates the AKT/Fox $\mathrm{O3}$ signalling pathway to restrict transforming growth factor-beta-mediated cytostatic signals. EMBO Rep 2005, 6(10):985-91.

38. Naka K, Hoshii T, Muraguchi T, Tadokoro Y, Ooshio T, Kondo Y, Nakao S, Motoyama N, Hirao A: TGF-beta-FOXO signalling maintains leukaemia- initiating cells in chronic myeloid leukaemia. Nature 2010, 463(7281):676-80

39. Zhao ZG, Li WM, Chen ZC, You Y, Zou P: Immunosuppressive properties of mesenchymal stem cells derived from bone marrow of patients with chronic myeloid leukemia. Immunol Invest 2008, 37(7):726-39.

\section{doi:10.1186/1756-9966-30-47}

Cite this article as: Xishan et al:: The research on the immunomodulatory defect of Mesenchymal Stem Cell from Chronic Myeloid Leukemia patients. Journal of Experimental \& Clinical Cancer Research 2011 30:47.

\section{Submit your next manuscript to BioMed Central and take full advantage of:}

- Convenient online submission

- Thorough peer review

- No space constraints or color figure charges

- Immediate publication on acceptance

- Inclusion in PubMed, CAS, Scopus and Google Scholar

- Research which is freely available for redistribution

Submit your manuscript at www.biomedcentral.com/submit
Biomed Central 